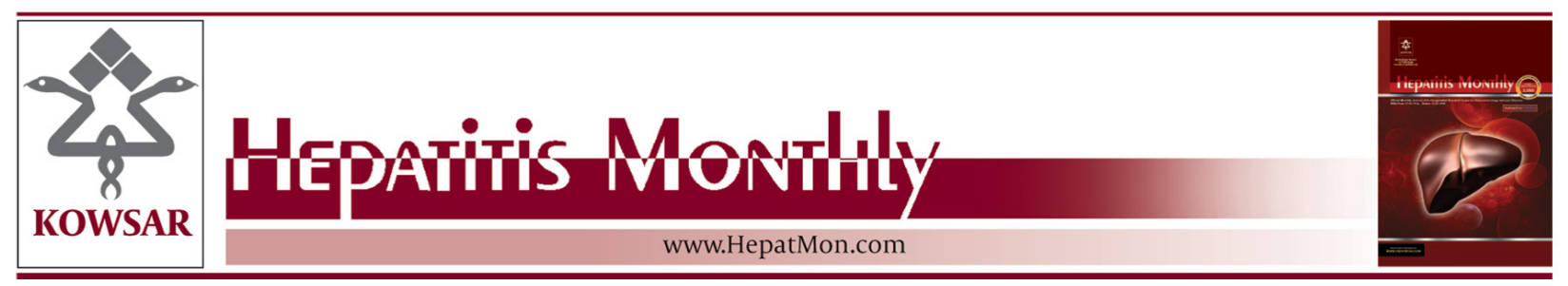

\title{
Probiotic as a Novel Treatment Strategy Against Liver Disease
}

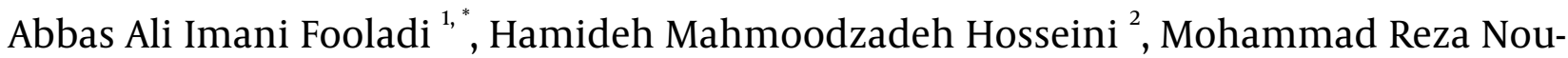 \\ rani $^{3}$, Soghra Khani ${ }^{4}$, Seyed Moayed Alavian ${ }^{5}$ \\ ${ }^{1}$ Applied Microbiology Research Center, Baqiyatallah University of Medical Sciences, Tehran, IR Iran \\ ${ }^{2}$ School of Pharmacy, Student's Research Committee, Tabriz University of Medical Sciences, Tabriz, IR Iran \\ ${ }^{3}$ Tissue Engineering Division, Chemical Injury Research Center, Baqiyatallah University of Medical Sciences, Tehran, IR Iran \\ ${ }^{4}$ Department of Biochemistry, Pasteur Institute of Iran, Tehran, IR Iran \\ ${ }^{5}$ Baqiyatallah Research Center for Gastroenterology and Liver Diseases, Baqiyatallah University of Medical Sciences, Tehran, IR Iran \\ * Corresponding author: Abbas Ali Imani Fooladi, Applied Microbiology Research Center, Baqiyatallah University of Medical Sciences, Tehran, IR Iran. Tel.: \\ +98-2188068924, Fax:+98-2188068924, E-mail: imanifouladi.a@gmail.com.
}

\begin{abstract}
A B S T R A C T
Context: A symbiotic relationship between the liver and intestinal tract enables the healthy status of both organs. Microflora resident in intestinal lumen plays a significant role in hepatocytes function. Alterations to the type and amount of microorganisms that live in the intestinal tract can result in serious and harmful liver dysfunctions such as cirrhosis, nonalcoholic fatty liver disease, alcoholic liver disease, and hepatic encephalopathy. An increased number of pathogens, especially enterobacteriaceae, enterococci, and streptococci species causes the elevation of intestinal permeability and bacterial translocation. The presence of high levels of lipopolysaccharide (LPS) and bacterial substances in the blood result in a portal hypertension and ensuing hepatocytes damage. Several methods including the usage of antibiotics, prebiotics, and probiotics can be used to prevent the overgrowth of pathogens. Compared to prebiotic and antibiotic therapy, probiotics strains are a safer and less expensive therapy. Probiotics are "live microorganisms (according to the FAO/WHO) which when administered in adequate amounts confer a health benefit on the host".

Evidence Acquisitions: Data from numerous preclinical and clinical trials allows for control of the flora bacteria quantity, decreases in compounds derived from bacteria, and lowers proinflammatory production such as TNF- $\alpha$, IL-6 and IFN- $\gamma$ via down-regulation of the nuclear factor kappa B (NF-k B).

Results: On the other hand, probiotic can reduce the urease activity of bacterial microflora. Furthermore, probiotic decreases fecal pH value and reduces ammonia adsorption. In addition, the serum level of liver enzymes and other substances synthesized by the liver are modulated subsequent to probiotic consumption.

Conclusions: According to our knowledge, Probiotic therapy as a safe, inexpensive and a noninvasive strategy can reduce pathophysiological symptoms and improve different types of liver diseases without side effects.
\end{abstract}

Keywords: Probiotics; Liver Cirrhosis, Nonalcoholic Fatty Liver Disease; Hepatic Encephalopathy; Liver Diseases, Alcoholic; Hepatitis; Carcinoma, Hepatocellular

Copyright () 2013, Kowsar Corp.; Published by Kowsar Corp.

Article type: Review Article; Received: 30 Jul 2012, Revised:19 Sep 2012, Accepted: 25 Sep 2012; DOI: 10.5812/hepatmon.7521

Implication for health policy/practice/research/medical education:

Probiotics are as live microorganisms which when administered in adequate amounts confer a health benefit on the host. Balanced and healthy conditions of gut enable to prevent a high percentage of liver abnormalities. Several studies, performed on discrepant diseases, confirmed positive influence of probiotic strains on pathophysiological symptoms.

Please cite this paper as:

Imani Fooladi AA, Mahmoodzadeh Hosseini H, Nourani MR, Khani S, Alavian SM. Probiotic as a novel treatment strategy against liver disease. HepatMon. 2013;13(2):e7521. DOI:105812/hepatmon.7521

Copyright @ 2013, Kowsar Corp.; Published by Kowsar Corp.

This is an Open Access article distributed under the terms of the Creative Commons Attribution License (http://creativecommons.org/licenses/by/3.0), which permits unrestricted use, distribution, and reproduction in any medium, provided the original work is properly cited. 


\section{Context}

Several endogenous and exogenous factors have negative consequences on the liver and cause destruction of the hepatic cells, thus leading to different kinds of liver diseases. Primary abnormal conditions such as alteration of microbial populations in intestinal tracts, have been known as common risk factors for obesity and diabetes type I (1). In addition, the gastrointestinal system has a close association with the liver. The gut, especially in the large intestine, contains large numbers of microorganisms. Almost 300 to 500 different kinds of species reside in it (2). The number of bacteria and their genes are more than the cells and genes belonging to each person. According to Neish study, $10^{9}$ colony forming units (CFU) $\mathrm{ml}$ and $10^{12} \mathrm{CFU} / \mathrm{ml}$ of bacteria may found in the terminal ileum and colon. Moreover, gram negative bacteria, and anaerobes are dominant species in the intestinal lumen which are estimated to be 100 to 1000 times more than aerobic ones. Bacteroides, Porphyromonas, Bifidobacterium, Lactobacillus, Clostridium and Escherichia coli (E. coli) are the most frequent ones (3). However, in each person, the pattern of microorganism population is unique and different (4). Indeed, microflora in the human gut lumen is a dynamic and complicated ecosystem which is capable of restoring itself and remains constant in most physiological conditions. In healthy individuals, the intestinal microflora contributes to various processes which affect the intestinal functions. Preparation of some substances such as nutrients, vitamin $\mathrm{K}$, folate, short chain fatty acids, and peroxides are some examples. In addition, bacteria can digest unabsorbed sugars including lactose together with alcohol, and produce short chain fatty acids which mucosa and enterocytes use as energy source. Modulation of the growth, proliferation, and differentiation of epithelial cells located in the intestine are other roles of these fatty acids (5). Furthermore, this complex ecosystem plays a key role to enhance immunity against pathogens entry to the body from external environment. Improvement of the host's defense system depends on the presence and activation of receptors such as TLRs (toll-like receptor), which can recognize the highly conserved pathogen-associated molecular patterns (PAMPs) $(3,6)$. Activation of the TLR promotes the production of cytokines, chemokines, and antimicrobial agents through the induction of NF-кB signaling $(7,8)$. Since the gut mucosa has a unique lymphoid tissue named as GALT (gut associated lymphoid tissue), interaction between the intestinal bacteria and this immune system leads to stimulation of adaptive type of immunity against PAMPs. Microorganisms existing in the microflora population were colonized in, and adhere to the intestinal mucosa, and prevent the growth and colonization of pathogen bacteria. Furthermore, secretion of specific bacteriocins by microflora inhibits the overgrowth of pathogens (5). Any disruption in the amount and composition of gut microflora results in a disturbance to the intestinal ho- meostasis. Increase in the pathogen population due to malfunction of microflora may lead to severe systematic infections (9). A close anatomical and functional relationship between two organs, the gut and the liver, is known as the gut-liver axis. Most blood supplied to the liver is supplied by the intestine via the portal vein. Blood circulated in the portal vein transfers various toxic compounds such as bacteria and their derivatives, substances produced by microflora including ethanol, ammonia, and acetaldehyde for filtration by liver and modulates kupffer cells activity and cytokine production. The increase of PAMPs and accumulation of metabolites in the liver can cause the liver harm. In return, the liver secretes bile acids to the intestine and modulates its activities (10). Alterations in the type and amount of microorganisms are important elements in the dysfunctions of the liver. Bacterial translocation (BT) occurs and there is an increased amount of microorganisms in the intestinal tract. The BT phenomenon is the migration of bacteria across the intestinal wall to extraintestinal site such as the mesenteric lymph nodes (11). Three factors including characteristics and nature of bacteria, functional properties of the intestinal wall, and local immunity affect the level of BT $(12,13)$. Some gram-negative species belonged to enterobacteriaceae, enterococci, and streptococci families are the most frequent bacteria which contribute to BT in patients with cirrhosis. These members, especially some strains of E. coli, could adhere to the mucosal surface on intestinal walls and pass across them efficiently. In contrast to higher levels of anaerobic species in microflora, they rarely participate in BT. High amounts of these anaerobic bacteria play a significant role in limiting the growth of species population which can translocate from the intestinal barrier (11). In addition, a multifactorial hypomotility consequent to adrenergic activity is one of the causes of overgrowth. It increases nitric oxide (NO) synthesis which leads to an impaired intestinal structure due to oxidative stress and portal hypertension (14-16). Furthermore, several previous studies reported that permeability changes in the intestine are able to enhance BT. The intestinal wall comprises mucosa, microvilli, enterocytes, and tight junctions attached to the apical surface of enterocytes (17-19). Abnormal changes in any part influence its permeability. Portal hypertension results in mucosa thickness via dilatation mucosa, the lamina propria edema, and proliferation of fibromuscular (20). In addition, increased lipid peroxidation, and oxidative stress in the brush cell membrane are effective in BT promotion (21). Tight junctions are second barriers to inhibit paracellular translocating of bacteria. Integrity impairment of tight junction structure leads to increased intestinal permeability (17). Another important factor interfering with intestinal permeability is a high concentration of toxic acetaldehyde produced via metabolism of ethanol due to large bowel bacteria overpopulation $(22,23)$. Increasing BT leads to the presence of a high quantity of 
LPS (24), and bacterial DNA (25) in circulation. Lack of hepatic clearance of these components from circulation is enhanced due to portal hypertension in liver disease. LPS as an endotoxin located in gram negative bacteria cell wall was recognized by TLR expressed on macrophages and stimulate proinflammatory cytokine secretions. Additionally, high amounts of bacterial DNA, and their derivatives induce the production of TNF- $\alpha$, IL-2, IL-6, IL-12, inducible nitric oxide synthesis, and nitric oxide $(25,26)$. In the liver, the extensive attachment of LPS to CD4/TLR4 induces high amounts of LPS-binding protein (24). Inefficient local immunity was demonstrated in liver disease; patients with cirrhosis in particular. The potent mechanism is depression in the activity of kupffer cells, and the reticular endothelium system which plays a significant role in defense against infected bacteria (27). Bile acids, secretary IgA, mucine, defensin, lysozyme and phospholipase $\mathrm{A} 2$ are agents which modulate bacterial growth in the intestine tract (28).

Our objective was to explain the role of probiotics as a bacteriotherapy strategy for treatment of some liver diseases.

\section{Evidence Acquisition}

\subsection{Probiotic}

According to the $\mathrm{FAO} / \mathrm{WHO}$ definition, probiotics are as "Live microorganisms which when administered in adequate amounts confer a health benefit on the host" (29). At the beginning of $20^{\text {th }}$ century, Elie Metchnikoff introduced a novel hypothesis about the health effects of probiotics. He claimed that the consumption of fermented milk products led to the health and longevity of Bulgarian peasants. Moreover, he stated that the organisms that lived in local yogurt were able to protect the intestine from the destructive effects of other pathogenic bacteria (30). Ideal probiotic strains have special properties such as resistance to bile, hydrochloric acid, and pancreatic juice; the ability to tolerate stomach and duodenum conditions and gastric transport; stimulation of the immune system, thereby improving intestinal function via adhering and colonizing the intestinal epithelium. In addition, probiotic strains competed with pathogens and modulated permeability, produced lactic acid, and exhibited anticarcinogenic and antipathogenic activity. Furthermore, these strains must be able to survive during the production processes and storage and still exert considerable healthful outcomes (31). Lactobacillus, Bifidobacterium, Escherichia, Enterococcus, Bacillus, Streptococcus, and some fungal Saccharomyces strains have been known as probiotics $(32,33)$. A powder, liquid, gel, paste, granule, capsule, sachet, and several kinds of food are available commercial products containing probiotics (34). It has been confirmed that $10^{8}$ to $10^{11} \mathrm{CFU}$ per day can demonstrably show the healthy effects of the probiotics (34,
35). Properties and effective actions of each probiotic are unique; therefore it is necessary to select a desired strain for treatment of each disorder. Several studies and clinical trials have been performed to assess the effects of various strains of probiotics for treating or preventing some diseases including special kinds of diarrhea, inflammatory bowel disease, cancer, Helicobacter pylori infection, vaginosis, hepatic disease allergy, lactose intolerance, high cholesterol levels, colitis, modulation of immune system, and several other abnormalities. Khani et al. published a useful review to shed light on these subjects (34).

\subsection{Gut Microflora in Pathogenesis of Liver Disease}

\subsubsection{Nonalcoholic Fatty Liver Disease (NAFLD)}

NAFLD is the most prevalent liver disease globally. It occurs in all age groups from children to adults (36). NAFLD includes an extensive range of disorders from steatosis to nonalcoholic steatohepatitis (NASH). A broad spectrum of histological manifestations including macrovesicular steatosis, liver cirrhosis, portal hypertension, and hepatocellular carcinoma are observed in NAFLD. A high amount of lipid storage in hepatocytes increases liver transaminase, and accumulation of necroinflammation components are indicators of a diseased condition (37). NAFLD is related to diabetes, insulin resistance, and obesity. Overall, complications of the metabolic syndrome are observed in these patients (36). Recently, two theories have been introduced regarding the manifestations of NASH. The first theory states that insulin resistance enables the transportation of fatty acids from adipose tissues to the liver. In the second one, excessive harmful compounds such as bacterial LPS, inflammatory inducer substances, and different substrates as energy sources (ethanol, short fatty acids) due to the overgrowth of gut microflora are known as causal factors (38). Overproduction of ethanol, endotoxin, and BT phenomena followed by abnormal growth of gram negative bacteria, stimulation of innate immunity in the liver and induction of hepatic oxidative damages result in liver injuries and cirrhosis (39).

\subsubsection{Alcoholic Liver Disease (ALD)}

ALD is a cause of a high rate of morbidity and mortality worldwide. Alcoholic steatohepatitis (ASH), and severe ALD manifest in approximately $30 \%$ of heavy drinkers (40). Therefore, other factors contribute to the emergence of ASH. Results from various in vivo studies performed on animals and humans reported that endotoxin produced by bacteria living in the bowel tracts functions as a cofactor. Furthermore, a high level of endotoxin has been seen in the plasma of these patients (41-45). Hyperpermeability of the intestine following by alcohol consumption leads to endotoxemia, which is filtrated by the liver and triggers the proinflammatory pathways for 
causing ASH. In addition, the leakiness of gut activates NF-kB transcription and overexpression of nitric oxide synthesis. Increased synthesis of NO results in oxidative stress in hepatocytes $(46,47)$. Alcohol consumption over a long period elevates the growth of gram negative bacteria and increases the amount of bifidobacteria and lactobacilli.

\subsubsection{Cirrhosis}

Cirrhosis, a vascular disease, is recognized by attributes such as portal hypertension, and hyperdynamic syndrome $(10,48)$. Similar to most liver diseases, the lack of equilibrium in gut normal-flora, and impairment of the intestinal barrier cause endotoxemia, a high level of proinflammatory cytokines, and NO synthesis induction (49, $50)$. Overgrowth of gut microflora, BT, and endotoxemia found in patients with cirrhosis supported the use of vascular shunts. As described before, these complications are accompanied with stimulation of inflammation and oxidative damage in liver which cause hepatocytes injuries (51).

\subsubsection{Primary sclerosing cholangitis (PSC)}

PSC is an autoimmune liver disease which involves bile ducts in and out of the liver. Cholestatic features of bile ducts are a result from progressive obliterative fibrosis. Although a close association between PSC and inflammatory bowel disease has been reported (52), however, its pathogenesis remains unknown. Immune and nonimmune mechanisms are suggested for the pathogenesis of PSC. There is a substantial amount of evidence that the lymphocytes located in the gut play a critical role for emerging PSC. On the other hand, bacteria residing in the gut may be a part of the cause of PSC through nonimmune routs (53). These microorganisms are able to release toxic compounds (54). Since the administration of antibiotics is an appropriate treatment for some patients with PSC $(54,55)$, there is a possibility indicating the role of bacterial flora together with intestinal inflammation in the pathogenesis of PSC.

\subsubsection{Hepatic Encephalopathy (HE)}

$\mathrm{HE}$ is a harmful complication following acute and chronic liver disease which occurs in at least 50\% to $70 \%$ of patients with cirrhosis $(56,57)$. This is a serious secondary neuropsychiatric syndrome which appears as a result of multi factors. Production of ammonia by the gut flora, and its release to the portal system are known as key factors to disrupt the central nerve system, and lead to hepatic encephalopathy (58).

\subsubsection{Viral Hepatitis}

Some viruses like hepatitis B and C virus (HBV and HCV) are known as causative agents leading to long term hepatocellular injury. High frequency of these viruses was reported in Iranian population (59). The plasma level of endotoxin increases in patients with HBV and HCV. Furthermore, high amounts of the proinflammatory cytokines described above and the necrosis reported in these patients cause liver damage in the longer term $(60,61)$. Results from a study of lactitol effect on amount of endotoxin in patients with HBV and HCV blood, showed that the alleviation of endotoxemia could be achieved by increasing bifidobacteria and lactobacillus numbers and avoiding the growth of pathogens (62).

\subsubsection{Hepatocellular Carcinoma (HCC)}

HCC is the most prevalent primary liver tumor which occurs after cirrhosis with a high frequency. Many risk factors such as a presence of viral antigens in chronic hepatitis B virus infections, carcinogenic mycotoxins, and compounds which produce reactive oxygen species alter molecular pathways in hepatocytes, in particular gene expression. For instance, aflatoxin, a strong mycotoxin, can attach to $\mathrm{G}$ nucleotides in the P53 gene and convert it to T and causes reduction of P53 transcription. In addition, inhibitory effects of aflatoxin on c-myc and bcl2 result in cell proliferation, and cancer progression (63-66).

\subsection{Probiotic Mechanisms in Liver Disease}

The beneficial effects of probiotics on liver health were observed in several studies. The primary mechanisms reported in these studies are the changes in gut functions (Figure 1). Consumption of probiotics could allow enterobacteriaceae through the competitive inhibition. Developing nutritional practices, mucosal barrier repairing, apoptosis prevention due to providing of short chain acids, and improving intestinal epithelial viability are other probiotic effects which stabilize physiological luminal permeability together with lowering ammonia adsorption (67). These functions alleviate tight junction disturbance by pathogens (68), and are essential agents for lowering BT. Induction of anaerobes and gram positive bacteria growth, limiting gram negative bacteria, and preventing pathogens adherents are other antitranslocation effects of the probiotics (69). Controlling flora bacteria quantity can lead to decreased endotoxins and other toxic compounds derived from bacteria such as ethanol, phenol, indoles which cause injury to the liver. Decreased levels of these substances in the liver result in lowering of proinflammatory production such as TNF- $\alpha$, IL-6, and IFN- $\gamma$ via down-regulation of the NF- $\mathrm{B}(70)$.On the other hand, they can depress urease activity of microflora bacteria followed by ammonia production and release in to the portal system. Furthermore, probiotic decreases fecal $\mathrm{pH}$ value and reduces ammonia adsorption (71). 


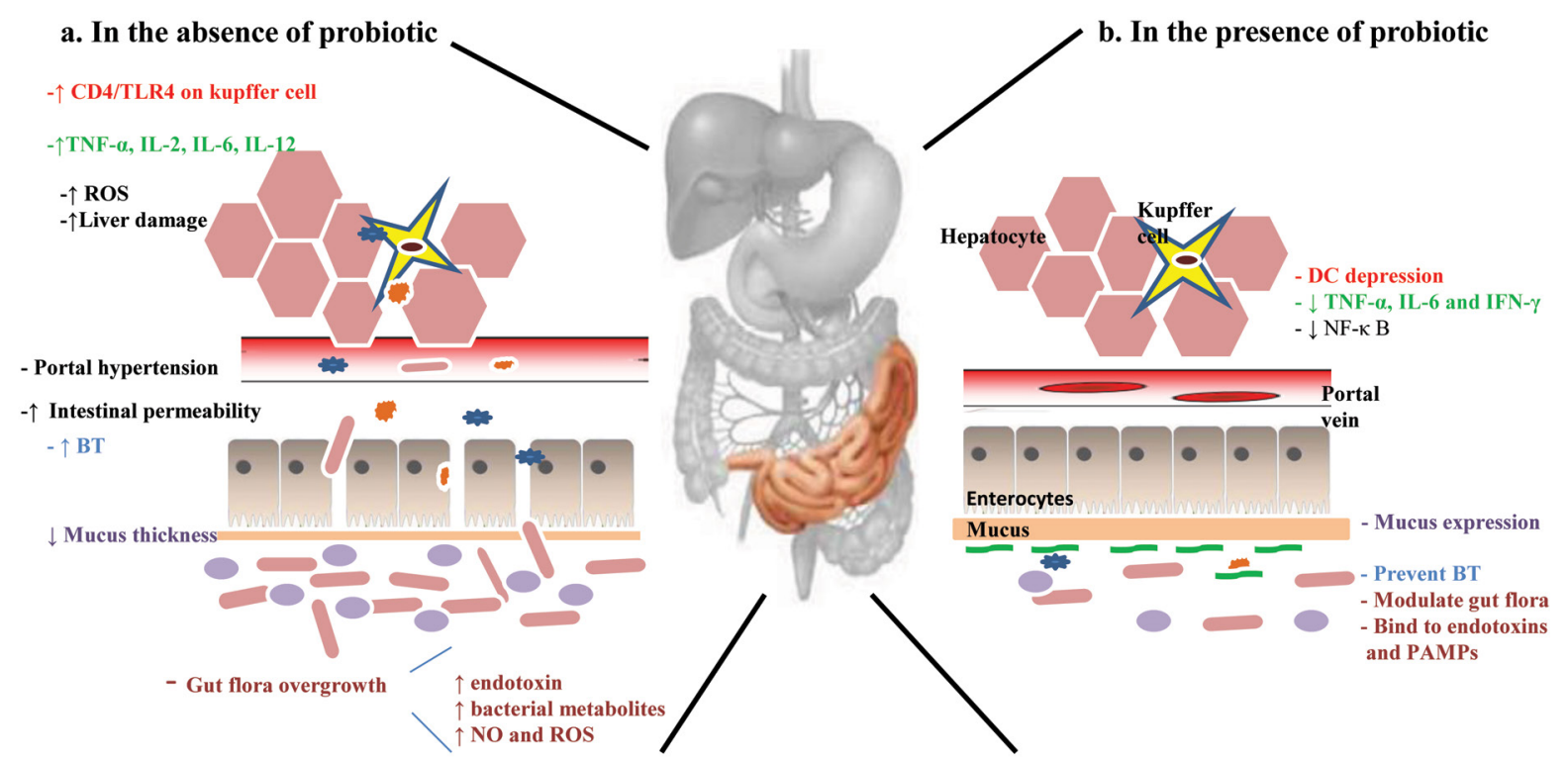

kupffer cells, hepatocytes, $\approx$ PAMPs, endotoxin, Aerobic bacteria, anaerobic

bacteria, - probiotic bacteria and ${ }^{-}$enterocytes.

Figure 1. a) Schematic Illustration of Multifarious Mechanisms Involved in Liver Diseases and b) Probiotic Influences on Them

\subsection{Probiotic as a Treatment Strategy of the Liver Disease}

\subsubsection{NAFLD}

Although NAFLD is known as a prevalent type of liver disease globally, the preferred therapy method has not been established. To conquer the overpopulation of pathogens, antibiotic therapy is the current strategy. Polymixin B and metronidazole are antibiotics which are currently used in these patients for ameliorating liver functions. However, it is not an appropriate therapy because of the unspecific ramifications to any bacteria (72). The usage of probiotic, prebiotic and symbiotic bacteria is recommended since these bacteria have the capacity to modulate microflora overpopulations and their consequent effect on the liver. In spite of the presence of various experimental studies in this field and positive effects of probiotic on induced liver steatosis (Table 1), the recognition of this strategy for treating or even preventing NAFLD is still complicated. Two subjects are relevant in this context. Firstly, the species of probiotics used in these studies varied. Most of these experiments were performed on the effects of VSL\#3 administration which itself contains a various species such as Streptococ- cus thermophilus, Bifidobacterium berve, Bifidobacterium longum, Bifidobacterium infanti, Lactobacillus acidophilus, Lactobacillus plantarum. Lactobacillus casei, and Lactobacillus bulgaricus (73-78) and determination of the effect of each species is unclear. Furthermore, most of them were tested on animal models and insufficient human clinical trials have been performed (Table 1). Therefore approving these bacteria as a treatment protocol requires several large scale clinical trials.

\subsection{2. $A L D$}

As already described, quantitative and qualitative alterations in the intestinal microflora are related to alcohol intake. In contrast to knowledge about most causative factors involved in the ALD pathogenesis, unfortunately, appropriate treatment of these patients is inconclusive as of yet. Since probiotic strains can modulate the gut and immune systems, it is suggested that probiotics can be administered to relieve ALD symptoms. Data from the studies designed to evaluate the role of probiotic supplementation in patients and animal models of ALD is summarized in Table 2. Improving the liver variables such as serum liver enzyme (alanin aminotransferase, aspartate aminotransferase and gamma glutamyl transferase), and total bilirubin, ameliorating hepatic inflammation and 


\begin{tabular}{|c|c|c|c|c|}
\hline Studies & $\begin{array}{l}\text { Participants/Dura- } \\
\text { tion }\end{array}$ & Treatment & Outcome & $\begin{array}{l}\text { Ref- } \\
\text { er- } \\
\text { ence }\end{array}$ \\
\hline Animal models & $\begin{array}{l}\text { Ob/ob mice fed HFD } \\
/ 4 \mathrm{w}\end{array}$ & VSL \# 3 & $\begin{array}{l}\text { hepatic FA content, ALT level, activity of } \\
\text { Jun N-terminal kinase, NF-kB and fatty acid } \\
\beta \text {-oxidation, improved hepatic IR, and NAFLD } \\
\text { histology }\end{array}$ & $(74)$ \\
\hline Animal models & mice fed HFD / $4 \mathrm{w}$ & VSL \# 3 & $\begin{array}{l}\text { Ameliorate hepatic NK cell depletion, steato- } \\
\text { sis, IR and inflammation, cholesterol and TG } \\
\text { in the liver and plasma }\end{array}$ & $(76)$ \\
\hline Animal models & mice fed HFD / $8 \mathrm{w}$ & Lactobacillus rhamnosus PL60 & $\begin{array}{l}\text { liver steatosis, improved histological steato- } \\
\text { sis manifestation }\end{array}$ & $(83)$ \\
\hline Animal models & $\begin{array}{l}\text { Rats fed HFD \& HCD } \\
/ 6 \mathrm{w}\end{array}$ & Bacillus polyfermenticus $S C D$ & LDL, cholesterol and triglycerides & $(84)$ \\
\hline Animal models & $\begin{array}{l}\text { Rats fed high-fructose } \\
\text { diet } / 8 \mathrm{w}\end{array}$ & $\begin{array}{l}\text { Lactobacillus acidophilus and } \\
\text { Lactobacillus casei }\end{array}$ & oxidative stress and ameliorate IR in liver & $(85)$ \\
\hline Animal models & Rats fed HCD / 5w & Lactobacillus plantarum MA2 & cholesterol and triglycerides & $(86)$ \\
\hline Animal models & Rats fed HFD / 4w & VSL \# 3 & $\begin{array}{l}\text { Improved the hepatic inflammatory, stea- } \\
\text { totic, peroxidative factors, serum amino- } \\
\text { transferase levels }\end{array}$ & $(73)$ \\
\hline Animal models & mice fed MCD / $9 \mathrm{w}$ & VSL \# 3 & $\begin{array}{l}\text { only improved liver fibrosis without effect on } \\
\text { statosis and inflammation }\end{array}$ & (78) \\
\hline Animal models & Rats/8 w & Lactobacillus paracasei F19 & $\begin{array}{l}\text { hepatic inflammation, steatosis and fibrosis, } \\
\text { innate inflammatory cytokines }\end{array}$ & $(87)$ \\
\hline Pilot study & $10 \mathrm{NASH}$ patients $/ 2 \mathrm{~m}$ & $\begin{array}{l}\text { L. acidophilus, L. bulgaricus, } B \text {. } \\
\text { lactis, B. bifidus, L. plantarum, } \\
\text { l. breve, L. casei, L. salivarus, } L . \\
\text { rhamnosus vsFOS and vitamin }\end{array}$ & $\begin{array}{l}\text { improved liver damage and liver function } \\
\text { test ALT, AST, and GGT activity Ameliorate } \\
\text { MDA and 4-HN plasma level }\end{array}$ & $(88)$ \\
\hline Open pilot & 22 patients $/ 3 \mathrm{~m}$ & VSL \# 3 & $\begin{array}{l}\text { improved liver damage and liver function } \\
\text { test ALT, AST, and GGT activity Ameliorate } \\
\text { MDA, and 4-HN plasma level }\end{array}$ & $(75)$ \\
\hline OL, pilot trial & 4 patients / $4 \mathrm{~m}$ & VSL \# 3 & $\begin{array}{l}\text { liver fat After washout time, no effects in } \\
\text { blood or clinical parameters }\end{array}$ & (77) \\
\hline R, DB, PC & 28 patients $/ 3 \mathrm{~m}$ & L. bulgaricus, S. thermophilus & ALT, AST, and GGT activity & $(89)$ \\
\hline
\end{tabular}

Abbreviation: ALT, alanin aminotransferase; AST, aspartate aminotransferase; DB, double-blind; d, day; FOS, fructo-oligosaccharide.synbiotic; GGT, gamma glutamyl transferase, m, month; HCD, high-cholesterol diet; HFD, high fat diet; MDA, malondialdehyde; 4-HN, 4-hydroxynonenal; OL, open labeled; PC, placebo-controlled; R, randomized; w, week.

histological grade are results from probiotic therapy in these studies.

\subsubsection{Cirrhosis}

Bacteriotherapy with probiotic strains in patients with cirrhosis can modulate bioecological system in the intestinal tract via prevention of the growth of pathogens, improvement to the mucosal layer, preservation of intestinal epithelia cells, and BT reduction. All of these mechanisms decrease portal hypertension due to inhibition of NO production followed by lowering plasma LPS (51). We performed further investigations to determine the effects of probiotics on cirrhosis than on other liver diseases. Data from several studies stated in Table 3 confirms the effects of probiotics.

\subsubsection{Primary Sclerosing Cholangitis}

As far as we know, only two studies assessed the potential of the effects of probiotics on patients with PSC. In a pilot study designed by Vleggaar et al., 14 patients with PSC with spontaneous inflammatory bowel disease were randomly administered Ecologic 641, the probiotic supplements with two Bifidobacillus and four Lactobacillus strains, or a placebo for three months. This treatment was performed as a double-blind manner. Results from this study demonstrated no improvement in pruritus, fatigue, and stool frequency. In addition, bilirubin, alkaline phosphatase, gamma glutamyl transpeptidase, aspartate aminotransferase, alanine aminotransferase, prothrombin, albumin, and bile salts levels were not significantly different between the probiotic and placebo groups (79). 
Table 2. Studies on Animal and Human Subjects with ALD

\begin{tabular}{|c|c|c|c|c|}
\hline Study models & Participants/Duration & Treatment & Outcome & Reference \\
\hline Animal models & Rat fed ethanol $/ 1 \mathrm{~m}$ & Lactobacillus GG & $\begin{array}{l}\text { Any hepatic pathologic alterations in induced } \\
\text { by alcohol, endotoxin level }\end{array}$ & $(90)$ \\
\hline Animal models & Rat fed ethanol / $10 \mathrm{w}$ & Lactobacillus GG & $\begin{array}{l}\text { Gut permeability, decreased hepatic and intesti- } \\
\text { nal oxidative stress and inflammation }\end{array}$ & (91) \\
\hline Animal models & Rat fed ethanol $/ 10 \mathrm{w}$ & Lactobacillus $G G$ and oats & Preventing alcohol-induced dysbiosis & $(92)$ \\
\hline Animal models & Mice fed ethanol / $35 \mathrm{~d}$ & $\begin{array}{l}\text { heat-killed Lactobacillus } \\
\text { brevis } S B C 8803\end{array}$ & $\begin{array}{l}\text { ALT, AST, TG, and cholesterol level Inhibit over- } \\
\text { expression of TNF-a, SREBP-1, SREBP-2 }\end{array}$ & $(93)$ \\
\hline DB, PC & 39 patients / $42 \mathrm{~d}$ & E. coli Nissle & $\begin{array}{l}\text { Improving intestinal colonization, and restore } \\
\text { physiological Microflora in faces, blood endo- } \\
\text { toxin level, Child-Pugh score. }\end{array}$ & $(94)$ \\
\hline $\begin{array}{l}\text { Open label } \\
\text { study }\end{array}$ & 12 patients / $4 \mathrm{w}$ & Lactobacillus casei Shirota & $\begin{array}{l}\text { Restore neutrophil function, Ex vivo endotoxin- } \\
\text { stimulated levels of sTNFR1, sTNFR2 and IL10 } \\
\text { normalized TLR4 expression }\end{array}$ & (95) \\
\hline $\begin{array}{l}\text { Open label } \\
\text { study, RCT }\end{array}$ & 66 patients / $5 \mathrm{~d}$ & $\begin{array}{l}\text { B. bifidumand Lactobacillus } \\
\text { plantarum } 8 \text { PA3 } v \text { sabsti- } \\
\text { nence plus vitamins }\end{array}$ & $\begin{array}{l}\text { Bifidobacteriaand Lactobacilli, ALT, AST , LDH } \\
\text { and total bilirubin }\end{array}$ & $(96)$ \\
\hline $\begin{array}{l}\text { Open pilot } \\
\text { study }\end{array}$ & 20 patients $/ 3 \mathrm{~m}$ & VSL\#3 & $\begin{array}{l}\text { Improving MDA, 4-HN, ALT, AST, GGT, TNF-a, IL-6, } \\
\text { and IL-10 levels }\end{array}$ & (75) \\
\hline
\end{tabular}

Abbreviation: ALT, alanin aminotransferase; AST, aspartate aminotransferase; DB, double-blind; d, day; GGT, gamma glutamyl transferase; MDA, malondialdehyde; 4-HN, 4-hydroxynonenal; m, month; OL, open labeled; PC, placebo-controlled; RCT, randomized clinical trial; SREBP-1, Sterol regulatory element-binding protein-1; w, week.

Table 3. Several Animal and Clinical Trial Studies on Cirrhosis

\begin{tabular}{|c|c|c|c|c|}
\hline & $\begin{array}{l}\text { Participants/ } \\
\text { Duration }\end{array}$ & Treatment & Outcome & Reference \\
\hline $\begin{array}{l}\text { Animal } \\
\text { models }\end{array}$ & $\begin{array}{l}\text { Cirrhotic Rat } \\
\text { induced by } \mathrm{CCl} 4 \\
/ 10 \mathrm{~d}\end{array}$ & Lactobacillus johnsonii La1 & $\begin{array}{l}\text { Intestinal enterobacteria and enterococci, } \\
\text { bacterial translocation, MDA levels }\end{array}$ & (97) \\
\hline $\begin{array}{l}\text { Animal } \\
\text { models }\end{array}$ & $\begin{array}{l}\text { Cirrhotic Rat } \\
\text { induced by } \mathrm{CCl} 4 \\
\text { / } 10 \mathrm{~d}\end{array}$ & Lactobacillus GG & $\begin{array}{l}\text { No effect on prevention of bacterial trans- } \\
\text { location }\end{array}$ & $(98)$ \\
\hline $\begin{array}{l}\text { Animal } \\
\text { models }\end{array}$ & $\begin{array}{l}\text { Rat with acute } \\
\text { liver injury } / 8 \mathrm{~d}\end{array}$ & $\begin{array}{l}\text { Bifidobacterium animalis NM2/ Lactobacillus } \\
\text { acidophilus NMI/Lactobacillus rhamnosus/ } \\
\text { Lactobacillus rhamnosus DSM 6594/Lactobacillus } \\
\text { plantarum DSM } 9843\end{array}$ & Prevented alcohol-induced dysbiosis & (99) \\
\hline DB, PC & 36 patients $/ 6 \mathrm{~m}$ & $\begin{array}{l}\text { Lactobacillus.acidophilus, Lactobacillus bulgari- } \\
\text { cus, Bifidobacterium lactis, S. thermophiles }\end{array}$ & $\begin{array}{l}\text { The ammonia levels starting after } 1 \mathrm{~m} / \mathrm{no} \\
\text { effect on liver enzyme }\end{array}$ & $(93,100)$ \\
\hline R, DB, PC & 65 patients $/ 6 \mathrm{~m}$ & Lactobacilli & $\begin{array}{l}\text { Incidence of HE, hospital admission, plas- } \\
\text { ma-ammonia level, serum bilirubin level }\end{array}$ & $(101)$ \\
\hline $\mathbf{R}$ & 50 patients $/ 14 \mathrm{~d}$ & $\begin{array}{l}\text { Bifidobacterium, L. acidophilusandEnterococcus } \\
\text { vs. Bacillus subtilisandEnterococcus faecium }\end{array}$ & $\begin{array}{l}\text { Bifidobacteriumcount, fecal pH, fecal and } \\
\text { blood ammonia in both groups, endotoxin } \\
\text { level only with B. subtilis and E. faecium }\end{array}$ & $(69)$ \\
\hline PPT & $\begin{array}{l}8 \text { patients with } \\
\text { HVPG }>10 \\
\mathrm{mmHg} / 2 \mathrm{~m}\end{array}$ & VSL \# 3 & $\begin{array}{l}\text { In plasma endotoxin, serum TNF- } \alpha \text {, plasma } \\
\text { aldosterone }\end{array}$ & $(102)$ \\
\hline RCT & $\begin{array}{l}41 \text { chronic liver } \\
\text { disease } / 14 \mathrm{~d}\end{array}$ & $\begin{array}{l}\text { B. bifidus, L. acidophilus, L. bulgaricus, and S. } \\
\text { thermophilus }\end{array}$ & $\begin{array}{l}\text { E. coli count, and intestinal flora imbalance, } \\
\text { improvement in debilitation, food intake, } \\
\text { abdominal distension, and ascitic fluid }\end{array}$ & $(103)$ \\
\hline $\begin{array}{l}\text { Pilot } \\
\text { study }\end{array}$ & 39 patients / $48 \mathrm{~d}$ & E. coli Nissle (Mutaflor) & $\begin{array}{l}\text { Improve intestinal colonization, endotoxin } \\
\text { levels on day } 42\end{array}$ & $(104)$ \\
\hline
\end{tabular}

Abbreviation: DB, double-blind; d, day; GGT; gamma glutamyl transferase; HE, hepatic encephalopathy; HVPG, hepatic venous pressure gradient; MDA, malondialdehyde; M, month; PC, placebo-controlled; PPT, perspective pilot study; RCT, randomized clinical trial; R, randomized; W, week. 
In a case report, a thirteen year-old boy with PSC has been treated with standard therapy by prednisolone, salazosulfapyridine together with Lactobacillus casei Shirota as a probiotic. After two weeks, clinical symptoms, and results from laboratory tests had shown improvement (80). Overall, these reports could not confirm the beneficial effects of probiotics on the treatment or prevention of PSC disease, and further studies might be needed.

\subsubsection{Hepatic Encephalopathy}

Evidence obtained from limited clinical trials performed on hepatic encephalopathy in human patients suggested that probiotic strains were able to decrease ammonia levels of serum, and improve neuropsycho- logical symptoms (Table 4). It appears that a reduction of bacterial urease activity, alleviation of $\mathrm{pH}$ and ammonia absorption, and decreased intestinal permeability are the beneficial effects of probiotics for treating hepatic encephalopathy (58). It is unfortunate that there are no appropriate animal models to assess minimal hepatic encephalopathy (MHE). Also, in human trial studies, the use of high levels of viable strain is ridiculous; therefore, the number and quantity of doses increase. Another disadvantage to these studies is the inability to use urease producing bacteria because of their dangerous properties to humans. In addition, the sampling size of this trial is small, and approving probiotics as a useful treatment method for MHE is dubious.

\begin{tabular}{|c|c|c|c|c|}
\hline & $\begin{array}{l}\text { Participants/ } \\
\text { Duration }\end{array}$ & Treatment & Outcome & Reference \\
\hline RCT & $\begin{array}{l}40 \text { patients/ } \\
\text { three } 4 \mathrm{w} \\
\text { with } 2 \text { weeks } \\
\text { washout }\end{array}$ & $\begin{array}{l}\text { Enterococcus faecium S68 / } \\
\text { lactolus }\end{array}$ & $\begin{array}{l}\text { Serum ammonia levels, improved various neurocogni- } \\
\text { tive tests }\end{array}$ & $(105)$ \\
\hline RCT & $\begin{array}{l}50 \text { patients / } \\
30 \mathrm{~d}\end{array}$ & $\begin{array}{l}\text { Fermentable fiber or symbi- } \\
\text { otic } 2000 v \text { splacebo }\end{array}$ & $\begin{array}{l}\text { Fecal content of on-urease-producing Lactobacillus spe- } \\
\text { cies, endotoxemia and blood ammonia levels, improve- } \\
\text { ment in Child-Turcotte-Pugh class in } 50 \% \text { of patients }\end{array}$ & $(106)$ \\
\hline $\begin{array}{l}\text { RCT, PC, } \\
\text { DB }\end{array}$ & 60 patients & $\begin{array}{l}\text { Bifidobacterium longum with } \\
\text { FOS vs placebo }\end{array}$ & $\begin{array}{l}\text { Improving neuropsychological testing, serum ammonia } \\
\text { levels }\end{array}$ & $(107)$ \\
\hline RCT & $\begin{array}{l}90 \text { patients } \\
13 \mathrm{~m}\end{array}$ & $\begin{array}{l}\text { LOLA or lactolus or probiot- } \\
\text { ic } v \text { splacebo }\end{array}$ & Improving blood ammonia levels & $(108)$ \\
\hline RCT & $\begin{array}{l}25 \text { patients / } \\
2 \mathrm{~m}\end{array}$ & Yogurt & Significant rate of MHE reversal & $(109)$ \\
\hline
\end{tabular}

Abbreviation: DB, double-blind; d, day; m, month; FOS, fructo-oligosaccharide; HE, hepatic encephalopathy; LOLA, L-ornithine L-aspartate; PC, placebocontrolled; RCT, randomized clinical trial; R, randomized; w, week.

\subsubsection{Viral Hepatitis}

To investigate the responses to the probiotic supplements of patients with cirrhosis due to viral infections, Loguerico et al. treated 20 patients with HCV-related chronic hepatitis and 16 with HCV-related cirrhosis with VSL\#3 (Streptococcus thermophilus, Bifidobacterium berve, Bifidobacterium longum, Bifidobacterium infanti, Lactobacillus acidophilus, Lactobacillus plantarum, Lactobacillus casei, and Lactobacillus bulgaricus) for four months. Aspartate aminotransferase, and alanin aminotransferase levels improved in two groups, and gamma glutamyl transferase improvement was observed only in HCV-related chronic hepatitis group (75). This area of liver damage requires more study to properly assess the benefits of probiotic therapy.

\subsubsection{Hepatocellular Carcinoma}

Few studies were performed to assess probiotic effects on toxicity of aflatoxin in liver dysfunction and hepatocellular carcinoma. In a research performed by El-Neza- mi, diminution of aflatoxin concentration was observed in fecal samples after the administration of Lactobacillus rhamnosus LC705 (81). In another five-week study, consumption of Lactobacillus rhamnosus LC705 together with Propionibacterium freudenreichii subsp. shermanii led to lower AFB-N7 guanine in urine samples when compared to a placebo (63). In recent in-vivo, Kumar et al. studied gene expression changes induced by Lactobacillus rhamnosus. GG consumption in rats exposed to aflatoxin. Concomitant with lowering of the c-myc, bcl2, cyclin D1 and rasp21 expression in treated rats compared to control group, the frequency of tumors in liver was alleviated (64).

\subsubsection{Liver transplantation}

Infection in a postoperative period is usually very prevalent in patients who have undergone liver transplantation. The most causative agents involved in these types of infections originate from the digestive tract (82). Generally, the results from four clinical trials performed on liver 
Table 5. Clinical Trials Assessed Probiotics Roles on Postoperative Infections in Liver Transplantation

\begin{tabular}{|c|c|c|c|c|}
\hline & $\begin{array}{l}\text { Participants/ } \\
\text { Duration }\end{array}$ & Treatment & Outcome & Reference \\
\hline RCT, PC & 95 recipients & $\begin{array}{l}\text { Lactobacillus plantarum and ferment- } \\
\text { able fiber, a heat-inactivated Lactoba- } \\
\text { cillus plantarum and fiber, or selective } \\
\text { intestinal decontamination }\end{array}$ & $\begin{array}{l}\text { Duration of antibiotic therapy and hospital stay } \\
\text { and intensive care unit stay, postoperative bacte- } \\
\text { rial infections incidence }\end{array}$ & $(82)$ \\
\hline $\begin{array}{l}\text { R, DB, } \\
\text { PC }\end{array}$ & $\begin{array}{l}66 \text { recipients } \\
\text { / } 15 \mathrm{~d}\end{array}$ & $\begin{array}{l}\text { P. pentosaceus, Leuconostoc mesen- } \\
\text { teroides, L. paracasei ssp. paracasei } \\
\text { F19, L. plantarum } 2362 \text { Vs.fibers }\end{array}$ & $\begin{array}{l}\text { Postoperative bacterial infections incidence, } \\
\downarrow \text { duration of antibiotic therapy }\end{array}$ & (110) \\
\hline DB, PC & $\begin{array}{l}25 \text { children } \\
\text { recipients / } \\
2 \mathrm{~m}\end{array}$ & L. casei strain DN-114001 vs.glucose & $\begin{array}{l}\beta \text {-glucuronidase, } \beta \text {-glucosidase, and urease, } \\
\text { changes in the intestinal microbiota }\end{array}$ & $(111)$ \\
\hline R, PC & $\begin{array}{l}50 \text { recipients } \\
/ 16 \mathrm{~d}\end{array}$ & $\begin{array}{l}\text { B. breve, L. casei, and galactooligosac- } \\
\text { charides }\end{array}$ & Postoperative bacterial infections incidence & $(112)$ \\
\hline
\end{tabular}

Abbreviation: DB, double-blind; d, day; m, month; PC, placebo-controlled; RCT, randomized clinical trial; R, randomized; w, week.

transplant patients described in Table 5, confirmed the inhibitory nature of probiotic consumption on postoperative infections.

\section{Conclusions}

A major instigate of liver disease is an anomaly in the gut flora. A balanced and healthy gut prevents a high percentage of harmful liver conditions. Several studies had been performed on various diseases, have confirmed the positive influence of probiotic strains on pathophysiological symptoms. Probiotic administration is safe, inexpensive and a noninvasive strategy as compared to antibiotic therapy and surgery. The expanding usage of antibiotics has resulted in the emergence of drug-resistant strains which pose a serious threat to humankind survival. Furthermore, the probiotic therapy shows no severe side effects unlike antibiotic therapy. Although results from clinical trials performed on common liver diseases showed the positive effects of probiotics, there are two problems that limit the usage of probiotics as a routine therapy. Since functional mechanisms of probiotic are specific to strain, recognize special strains with the highest prophylactic, and preventive properties on liver disease may be required. Also, engineering probiotics for specific, desirable properties might be useful. Lastly, to confirm the viability of bacteriotherapy, more clinical trials in various countries with disparate races, ethnicity, and lifestyles would be required.

\section{Acknowledgements}

None declared.

\section{Authors' Contribution}

Abbas Ali Imani Fooladi is corresponding and main author. Hamideh Mahmoodzadeh Hosseini is scientific editor, figure designer and main author, Mohammad Reza Nourani is scientific editor and main co-author, Soghra Khani, suggested figure designer. Seyed Moayed Alavian is liver disease consulter and scientific editor.

\section{Financial Disclosure}

None declared.

\section{Funding/Support}

None declared.

\section{References}

1. Solga SF, Diehl AM. Non-alcoholic fatty liver disease: lumenliver interactions and possible role for probiotics. $J$ Hepatol. 2003;38(5):681-7.

2. Palmer C, Bik EM, DiGiulio DB, Relman DA, Brown PO. Development of the human infant intestinal microbiota. PLoS Biol. 2007;5(7):e177.

3. Neish AS. Microbes in gastrointestinal health and disease. Gastroenterology. 2009;136(1):65-80.

4. Guarner F, Malagelada JR. Gut flora in health and disease. Lancet. 2003;361(9356):512-9.

5. O'Hara AM, Shanahan F. Gut microbiota: mining for therapeutic potential. Clin Gastroenterol Hepatol. 2007;5(3):274-84.

6. Imani Fooladi AA, Mousavi SF, Seghatoleslami S, Yazdani S, Nourani MR. Toll-like receptors: role of inflammation and commensal bacteria. Inflamm Allergy Drug Targets. 2011;10(3):198-207.

7. Imanifooladi AA, Yazdani S, Nourani MR. The role of nuclear factor-kappaB in inflammatory lung disease. Inflamm Allergy Drug Targets. 2010;9(3):197-205.

8. Zhang G, Ghosh S. Toll-like receptor-mediated NF-kappaB activation: a phylogenetically conserved paradigm in innate immunity. J Clin Invest. 2001;107(1):13-9.

9. Quigley EM. Prebiotics and probiotics; modifying and mining the microbiota. Pharmacol Res. 2010;61(3):213-8.

10. Cesaro C, Tiso A, Del Prete A, Cariello R, Tuccillo C, Cotticelli G, et al. Gut microbiota and probiotics in chronic liver diseases. Dig Liver Dis. 2011;43(6):431-8.

11. Riordan SM, Williams R. The intestinal flora and bacterial infection in cirrhosis. J Hepatol. 2006;45(5):744-57.

12. Luyer MD, Buurman WA, Hadfoune M, Speelmans G, Knol J, Jacobs JA, et al. Strain-specific effects of probiotics on gut barrier integrity following hemorrhagic shock. Infect Immun. 2005;73(6):3686-92.

13. Rachmilewitz D, Katakura K, Karmeli F, Hayashi T, Reinus C, Rudensky B, et al. Toll-like receptor 9 signaling mediates the anti-inflammatory effects of probiotics in murine experimental colitis. Gastroenterology. 2004;126(2):520-8.

14. Bauer TM, Steinbruckner B, Brinkmann FE, Ditzen AK, Schwacha $\mathrm{H}$, Aponte JJ, et al. Small intestinal bacterial overgrowth in patients with cirrhosis: prevalence and relation with spontaneous 
bacterial peritonitis. Am J Gastroenterol. 2001;96(10):2962-7.

15. Chang CS, Chen GH, Lien HC, Yeh HZ. Small intestine dysmotility and bacterial overgrowth in cirrhotic patients with spontaneous bacterial peritonitis. Hepatology. 1998;28(5):1187-90.

16. Gunnarsdottir SA, Sadik R, Shev S, Simren M, Sjovall H, Stotzer PO, et al. Small intestinal motility disturbances and bacterial overgrowth in patients with liver cirrhosis and portal hypertension. Am J Gastroenterol. 2003;98(6):1362-70.

17. Madrid AM, Hurtado C, Venegas M, Cumsille F, Defilippi C. Long Term treatment with cisapride and antibiotics in liver cirrhosis: effect on small intestinal motility, bacterial overgrowth, and liver function. Am J Gastroenterol. 2001;96(4):1251-5.

18. Salzman AL, Menconi MJ, Unno N, Ezzell RM, Casey DM, Gonzalez PK, et al. Nitric oxide dilates tight junctions and depletes ATP in cultured Caco-2BBe intestinal epithelial monolayers. Am J Physiol. 1995;268(2 Pt 1):G361-73.

19. Such J, Guardiola JV, de Juan J, Casellas JA, Pascual S, Aparicio JR, et al. Ultrastructural characteristics of distal duodenum mucosa in patients with cirrhosis. Eur J Gastroenterol Hepatol. 2002;14(4):371-6.

20. Misra V, Misra SP, Dwivedi M, Gupta SC. Histomorphometric study of portal hypertensive enteropathy. Am J Clin Pathol. 1997;108(6):652-7.

21. Ramachandran A, Prabhu R, Thomas S, Reddy JB, Pulimood A, Balasubramanian KA. Intestinal mucosal alterations in experimental cirrhosis in the rat: role of oxygen free radicals. Hepatol ogy. 2002;35(3):622-9.

22. Bode C, Bode JC. Effect of alcohol consumption on the gut. Best Pract Res Clin Gastroenterol. 2003;17(4):575-92.

23. Visapaa JP, Tillonen J, Salaspuro M. Microbes and mucosa in the regulation of intracolonic acetaldehyde concentration during ethanol challenge. Alcohol Alcohol. 2002;37(4):322-6.

24. Albillos A, de la Hera A, Gonzalez M, Moya JL, Calleja JL, Monserra $\mathrm{J}$, et al. Increased lipopolysaccharide binding protein in cirrhotic patients with marked immune and hemodynamic derangement. Hepatology. 2003;37(1):208-17.

25. Frances R, Rodriguez E, Munoz C, Zapater P, De la ML, Ndongo M, et al. Intracellular cytokine expression in peritoneal monocyte macrophages obtained from patients with cirrhosis and presence of bacterial DNA. Eur J Gastroenterol Hepatol. 2005;17(1):45-51.

26. Frances R, Munoz C, Zapater P, Uceda F, Gascon I, Pascual S, et al. Bacterial DNA activates cell mediated immune response and nitric oxide overproduction in peritoneal macrophages from patients with cirrhosis and ascites. Gut. 2004;53(6):860-4.

27. Rimola A, Soto R, Bory F, Arroyo V, Piera C, Rodes J. Reticuloendothelial system phagocytic activity in cirrhosis and its relation to bacterial infections and prognosis. Hepatology. 1984;4(1):53-8.

28. Levi AC, Borghi F, Petrino R, Bargoni A, Fronticelli CM, Gentilli S. Modifications of the trophism of intestinal mucosa after intestinal and bilio-pancreatic diversion in the rat. Ital J Gastroenterol. 1991;23(4):202-7.

29. Culligan EP, Hill C, Sleator RD. Probiotics and gastrointestinal disease: successes, problems and future prospects. Gut Pathog. 2009;1(1):19.

30. Metchnikoff E. Lactic acid as inhibiting intestinal putrefaction. The prolongation of life: Optimistic studies. London: William Heinemann; 1907. pp.161-83.

31. Lin WH, Hwang CF, Chen LW, Tsen HY. Viable counts, characteristic evaluation for commercial lactic acid bacteria products. Food Microbiol. 2006;23(1):74-81.

32. Gupta V, Garg R. Probiotics. Indian J Med Microbiol. 2009;27(3):202-9.

33. Parvez S, Malik KA, Ah Kang S, Kim HY. Probiotics and their fermented food products are beneficial for health. J Appl Microbiol. 2006;100(6):1171-85.

34. Khani S, Hosseini HM, Taheri M, Nourani MR, Imani Fooladi AA Probiotics as an alternative strategy for prevention and treatment of human diseases: a review. Inflamm Allergy Drug Targets. 2012;11(2):79-89.

35. Ndagijimana M, Laghi L, Vitali B, Placucci G, Brigidi P, Guerzoni ME. Effect of a synbiotic food consumption on human gut metabolic profiles evaluated by (1)H Nuclear Magnetic Resonance spectroscopy. Int J Food Microbiol. 2009;134(1-2):147-53.

36. Cope K, Risby T, Diehl AM. Increased gastrointestinal ethano production in obese mice: implications for fatty liver disease pathogenesis. Gastroenterology. 2000;119(5):1340-7.

37. Khosravi S, Alavian SM, Zare A, Daryani NE, Fereshtehnejad SM, Keramati MR, et al. Non-alcoholic fatty liver disease and correlation of serum alanin aminotransferase level with histopathologic findings. Hepat Mon. 2011;11(6):452-8.

38. Law K, Brunt EM. Nonalcoholic fatty liver disease. Clin Liver Dis. 2010;14(4):591-604.

39. Compare D, Coccoli P, Rocco A, Nardone OM, De Maria S, Carteni $\mathrm{M}$, et al. Gut-liver axis: the impact of gut microbiota on non alcoholic fatty liver disease. Nutr Metab Cardiovasc Dis. 2012;22(6):4716

40. Gramenzi A, Caputo F, Biselli M, Kuria F, Loggi E, Andreone P, et al. Review article: alcoholic liver disease-pathophysiological aspects and risk factors. Aliment Pharmacol Ther. 2006;24(8):1151-61.

41. Bode C, Kugler V, Bode JC. Endotoxemia in patients with alcoholic and non-alcoholic cirrhosis and in subjects with no evidence of chronic liver disease following acute alcohol excess. J Hepatol. 1987; $\mathbf{4}(1): 8-14$

42. Fukui H, Brauner B, Bode JC, Bode C. Plasma endotoxin concentrations in patients with alcoholic and non-alcoholic liver disease: reevaluation with an improved chromogenic assay. J Hepatol.1991;12(2):162-9.

43. Lumsden AB, Henderson JM, Kutner MH. Endotoxin levels measured by a chromogenic assay in portal, hepatic and peripheral venous blood in patients with cirrhosis. Hepatology. 1988;8(2):232-6.

44. Thurman RG. II. Alcoholic liver injury involves activation of Kupffer cells by endotoxin. Am J Physiol. 1998;275(4 Pt 1):G605-11.

45. Tilg H, Diehl AM. Cytokines in alcoholic and nonalcoholic steatohepatitis. N Engl J Med. 2000;343(20):1467-76.

46. Banan A, Fields JZ, Decker H, Zhang Y, Keshavarzian A. Nitric oxide and its metabolites mediate ethanol-induced microtubule disruption and intestinal barrier dysfunction. J Pharmacol Exp Ther. 2000;294(3):997-1008.

47. Banan A, Keshavarzian A, Zhang L, Shaikh M, Forsyth CB, Tang Y, et al. NF-kappaB activation as a key mechanism in ethanol-induced disruption of the F-actin cytoskeleton and monolayer barrier integrity in intestinal epithelium. Alcohol. 2007;41(6):447-60.

48. Iwakiri Y, Groszmann RJ. The hyperdynamic circulation of chronic liver diseases: from the patient to the molecule. Hepatology. 2006;43(2 Suppl 1):S121-31.

49. Chu CJ, Lee FY, Wang SS, Lu RH, Tsai YT, Lin HC, et al. Hyperdynamic circulation of cirrhotic rats with ascites: role of endotoxin, tumour necrosis factor-alpha and nitric oxide. Clin Sc (Lond). 1997;93(3):219-25.

50. Guarner C, Soriano G, Tomas A, Bulbena O, Novella MT, Balanzo J, et al. Increased serum nitrite and nitrate levels in patients with cirrhosis: relationship to endotoxemia. Hepatology. 1993;18(5):1139-43.

51. Wiest R, Das S, Cadelina G, Garcia-Tsao G, Milstien S, Groszmann RJ. Bacterial translocation in cirrhotic rats stimulates eNOS-derived NO production and impairs mesenteric vascular contractility.J Clin Invest. 1999;104(9):1223-33.

52. Faubion WA, Jr., Loftus EV, Sandborn WJ, Freese DK, Perrault J Pediatric "PSC-IBD": a descriptive report of associated inflammatory bowel disease among pediatric patients with psc.J Pediat Gastroenterol Nutr. 2001;33(3):296-300.

53. Grant AJ, Lalor PF, Hubscher SG, Briskin M, Adams DH. MAdCAM-1 expressed in chronic inflammatory liver disease supports mucosal lymphocyte adhesion to hepatic endothelium (MAdCAM-1 in chronic inflammatory liver disease). Hepatology. 2001;33(5):1065-72.

54. Davies YK, Cox KM, Abdullah BA, Safta A, Terry AB, Cox KL. Long term treatment of primary sclerosing cholangitis in children with oral vancomycin: an immunomodulating antibiotic. J Pediatr Gastroenterol Nutr. 2008;47(1):61-7.

55. Elfaki DA, Lindor KD. Antibiotics for the treatment of primary sclerosing cholangitis. Am J Ther. 2011;18(3):261-5.

56. Blei AT, Cordoba J. Hepatic Encephalopathy. Am J Gastroenter- 
ol. 2001;96(7):1968-76.

57. Weissenborn K, Ennen JC, Schomerus H, Ruckert N, Hecker H. Neuropsychological characterization of hepatic encephalopathy. J Hepatol. 2001;34(5):768-73.

58. Solga SF. Probiotics can treat hepatic encephalopathy. Med Hypotheses. 2003;61(2):307-13.

59. Alavian SM, Gholami B, Masarrat S. Hepatitis C risk factors in Iranian volunteer blood donors: a case-control study.J Gastroentero Hepatol. 2002;17(10):1092-7.

60. SozinovAS. Possible participation of endotoxin of gram-negative bacteria in pathogenesis of liver damage during viral hepatitis. Bull Exp Biol Med. 2002;133(3):281-4.

61. Sozinov AS. Systemic endotoxemia during chronic viral hepatitis. Bull Exp Biol Med. 2002;133(2):153-5.

62. Chen C, Li L, Wu Z, Chen H, Fu S. Effects of lactitol on intestinal microflora and plasma endotoxin in patients with chronic viral hepatitis. J Infect. 2007;54(1):98-102.

63. El-Nezami HS, Polychronaki NN, Ma J, Zhu H, Ling W, Salminen EK, et al. Probiotic supplementation reduces a biomarker for increased risk of liver cancer in young men from Southern China. Am JClin Nutr. 2006;83(5):1199-203.

64. Kumar M, Verma V, Nagpal R, Kumar A, Gautam SK, Behare PV, et al. Effect of probiotic fermented milk and chlorophyllin on gene expressions and genotoxicity during $\mathrm{AFB}(1)$-induced hepatocellular carcinoma. Gene. 2011;490(1-2):54-9.

65. Smela ME, Currier SS, Bailey EA, Essigmann JM. The chemistry and biology of aflatoxin $\mathrm{B}(1)$ : from mutational spectrometry to carcinogenesis. Carcinogenesis.2001;22(4):535-45.

66. Yeh FS, Yu MC, Mo CC, Luo S, Tong MJ, Henderson BE. Hepatitis B virus, aflatoxins, and hepatocellular carcinoma in southern Guangxi, China. Cancer Res. 1989;49(9):2506-9.

67. Kanauchi O, Fujiyama Y, Mitsuyama K, Araki Y, Ishii T, Nakamura T, et al. Increased growth of Bifidobacterium and Eubacterium by germinated barley foodstuff, accompanied by enhanced butyrate production in healthy volunteers. Int J Mol Med.1999;3(2):175-

68. Johnson-Henry KC, Donato KA, Shen-Tu G, Gordanpour M, Sherman PM. Lactobacillus rhamnosus strain GG prevents enterohemorrhagic Escherichia coli O157:H7-induced changes in epithelial barrier function. Infect Immun. 2008;76(4):1340-8.

69. Zhao HY, Wang HJ, Lu Z, Xu SZ. Intestinal microflora in patients with liver cirrhosis. Chin J Dig Dis. 2004;5(2):64-7.

70. O'Sullivan DJ. Genomics can advance the potential for probiotic cultures to improve liver and overall health. Curr Pharm Des. 2008;14(14):1376-81.

71. Clausen MR, Mortensen PB. Lactulose, disaccharides and colonic flora. Clinical consequences. Drugs. 1997;53(6):930-42.

72. Miele L, Valenza V, La Torre G, Montalto M, Cammarota G, Ricci R, et al. Increased intestinal permeability and tight junction alterations in nonalcoholic fatty liver disease. Hepatology. 2009;49(6):1877-87.

73. Esposito E, Iacono A, Bianco G, Autore G, Cuzzocrea S, Vajro P, et al. Probiotics reduce the inflammatory response induced by a high-fat diet in the liver of young rats. J Nutr. 2009;139(5):905-11.

74. Li Z, Yang S, Lin H, Huang J, Watkins PA, Moser AB, et al. Probiotics and antibodies to TNF inhibit inflammatory activity and improve nonalcoholic fatty liver disease. Hepatology.\$2003;37(2):343-50.

75. Loguercio C, Federico A, Tuccillo C, Terracciano F, D'Auria MV, De Simone C, et al. Beneficial effects of a probiotic VSL\#3 on parameters of liver dysfunction in chronic liver diseases. J Clin Gastroenterol. 2005;39(6):540-3.

76. Ma X, Hua J, Li Z. Probiotics improve high fat diet-induced hepatic steatosis and insulin resistance by increasing hepatic NKT cells. J Hepatol.2008;49(5):821-30.

77. Solga SF, Buckley G, Clark JM, Horska A, Diehl AM. The effect of a probiotic on hepatic steatosis. J Clin Gastroenterol. 2008;42(10):1117-9.

78. Velayudham A, Dolganiuc A, Ellis M, Petrasek J, Kodys K, Mandrekar P, et al. VSL\#3 probiotic treatment attenuates fibrosis without changes in steatohepatitis in a diet-induced nonalcoholic steatohepatitis model in mice. Hepatology. 2009;49(3):989-97.

79. Vleggaar FP, Monkelbaan JF, van Erpecum KJ. Probiotics in prima- ry sclerosing cholangitis: a randomized placebo-controlled crossover pilot study. Eur J Gastroenterol Hepatol. 2008;20(7):688-92.

80. Shimizu M, Iwasaki H, Mase S, Yachie A. Successful treatment of primary sclerosing cholangitis with a steroid and a probiotic. Case Rep Gastroenterol. 2012;6(2):249-53.

81. El-Nezami H, Kankaanpää P, Suomalainen T, Ahokas J, Salminen S. The ability of a mixture of Lactobacillus and Propionibacterium to influence the faecal recovery of aflatoxins in healthy Egyptian volunteers: a pilot clinical study. Biosci Microflora. 2000;19(4):41-5

82. Rayes N, Seehofer D, Hansen S, Boucsein K, Muller AR, Serke S, et al. Early enteral supply of lactobacillus and fiber versus selective bowel decontamination: a controlled trial in liver transplant recipients. Transplantation. 2002;74(1):123-7.

83. Lee HY, Park JH, Seok SH, Baek MW, Kim DJ, Lee KE, et al. Human originated bacteria, Lactobacillus rhamnosus PL60, produce conjugated linoleic acid and show anti-obesity effects in dietinduced obese mice. Biochim Biophys Acta. 2006;1761(7):736-44.

84. Paik HD, Park JS, Park E. Effects of Bacillus polyfermenticus SCD on lipid and antioxidant metabolisms in rats fed a high-fat and high-cholesterol diet. Biol Pharm Bull. 2005;28(7):1270-4.

85. Yadav H, Jain S, Sinha PR. Antidiabetic effect of probiotic dahi containing Lactobacillus acidophilus and Lactobacillus casei in high fructose fed rats. Nutrition. 2007;23(1):62-8.

86. Wang Y, Xu N, Xi A, Ahmed Z, Zhang B, Bai X. Effects of Lactobacillus plantarum MA2 isolated from Tibet kefir on lipid metabolism and intestinal microflora of rats fed on high-cholesterol diet. Appl Microbiol Biotechnol. 2009;84(2):341-7.

87. Nardone G, Compare D, Liguori E, Di Mauro V, Rocco A, Barone $\mathrm{M}$, et al. Protective effects of Lactobacillus paracasei F19 in a rat model of oxidative and metabolic hepatic injury. Am J Physiol Gastrointest Liver Physiol. 2010;299(3):G669-76.

88. Loguercio C, De Simone T, Federico A, Terracciano F, Tuccillo C, Di Chicco M, et al. Gut-liver axis: a new point of attack to treat chronic liver damage? Am J Gastroenterol. 2002;97(8):2144-6.

89. Aller R, De Luis DA, Izaola O, Conde R, Gonzalez Sagrado M, Primo $\mathrm{D}$, et al. Effect of a probiotic on liver aminotransferases in nonalcoholic fatty liver disease patients: a double blind randomized clinical trial. Eur Rev Med Pharmacol Sci. 2011;15(9):1090-5.

90. Nanji AA, Khettry U, Sadrzadeh SM. Lactobacillus feeding reduces endotoxemia and severity of experimental alcoholic liver (disease). Proc Soc Exp Biol Med. 1994;205(3):243-7.

91. Forsyth CB, Farhadi A, Jakate SM, Tang Y, Shaikh M, Keshavarzian A. Lactobacillus GG treatment ameliorates alcohol-induced intestinal oxidative stress, gut leakiness, and liver injury in a rat model of alcoholic steatohepatitis. Alcohol. 2009;43(2):163-72.

92. Mutlu E, Keshavarzian A, Engen P, Forsyth CB, Sikaroodi M, Gillevet P. Intestinal dysbiosis: a possible mechanism of alcohol-induced endotoxemia and alcoholic steatohepatitis in rats. Alcohol Clin Exp Res. 2009;33(10):1836-46.

93. Segawa S, Wakita Y, Hirata H, Watari J. Oral administration of heat-killed Lactobacillus brevis SBC8803 ameliorates alcoholic liver disease in ethanol-containing diet-fed C57BL/6N mice. Int J Food Microbiol. 2008;128(2):371-7.

94. Lata J, Novotny I, Pribramska V, Jurankova J, Fric P, Kroupa R, et al. The effect of probiotics on gut flora, level of endotoxin and Child-Pugh score in cirrhotic patients: results of a double-blind randomized study. Eur J Gastroenterol Hepatol. 2007;19(12):1111-3.

95. Stadlbauer V, Mookerjee RP, Hodges S, Wright GA, Davies NA Jalan R. Effect of probiotic treatment on deranged neutrophil function and cytokine responses in patients with compensated alcoholic cirrhosis.J Hepatol. 2008;48(6):945-51.

96. Kirpich IA, Solovieva NV, Leikhter SN, Shidakova NA, Lebedeva OV, Sidorov PI, et al. Probiotics restore bowel flora and improve liver enzymes in human alcohol-induced liver injury: a pilot study. Alcohol. 2008;42(8):675-82.

97. Chiva M, Soriano G, Rochat I, Peralta C, Rochat F, Llovet T, et al. Effect of Lactobacillus johnsonii La1 and antioxidants on intestinal flora and bacterial translocation in rats with experimental cirrhosis. J Hepatol. 2002;37(4):456-62.

98. Bauer TM, Fernandez J, Navasa M, Vila J, Rodes J. Failure of Lactobacillus spp. to prevent bacterial translocation in a rat model of experimental cirrhosis. J Hepatol. 2002;36(4):501-6. 
99. Adawi D, Ahrne S, Molin G. Effects of different probiotic strains of Lactobacillus and Bifidobacterium on bacterial translocation and liver injury in an acute liver injury model. Int J Food Microbiol. 2001;70(3):213-20.

100. Pereg D, Kotliroff A, Gadoth N, Hadary R, Lishner M, Kitay-Cohen Y. Probiotics for patients with compensated liver cirrhosis: a double-blind placebo-controlled study. Nutrition. 2011;27(2):177-81.

101. Pawar R, Pardeshi M, Ghongane B. Study of Effects of Probiotic Lactobacilli in Preventing Major Complications in Patients of Liver Cirrhosis. Intl J Biomed Pharma Sci. 2012;3(1):206-11.

102. Tandon P, Moncrief K, Madsen K, Arrieta MC, Owen RJ, Bain VG, et al. Effects of probiotic therapy on portal pressure in patients with cirrhosis: a pilot study. Liver Int. 2009;29(7):1110-5.

103. Liu JE, Zhang Y, Zhang J, Dong PL, Chen M, Duan ZP. Probiotic yogurt effects on intestinal flora of patients with chronic liver disease. Nurs Res. 2010;59(6):426-32.

104. Lata J, Jurankova J, Pribramska V, Fric P, Senkyrik M, Dite P, et al. [Effect of administration of Escherichia coli Nissle (Mutaflor) on intestinal colonisation, endo-toxemia, liver function and minimal hepatic encephalopathy in patients with liver cirrhosis]. Vnitr Lek. 2006;52(3):215-9.

105. Loguercio C, Abbiati R, Rinaldi M, Romano A, Del Vecchio Blanco C, Coltorti M. Long-term effects of Enterococcus faecium SF68 versus lactulose in the treatment of patients with cirrhosis and grade 1-2 hepatic encephalopathy. J Hepatol.1995;23(1):39-46.

106. Liu Q, Duan ZP, Ha DK, Bengmark S, Kurtovic J, Riordan SM. Synbiotic modulation of gut flora: effect on minimal hepatic encepha- lopathy in patients with cirrhosis. Hepatology. 2004;39(5):1441-9.

107. Malaguarnera M, Greco F, Barone G, Gargante MP, Toscano MA. Bifidobacterium longum with fructo-oligosaccharide (FOS) treatment in minimal hepatic encephalopathy: a randomized, double-blind, placebo-controlled study. Dig Dis Sci. 2007;52(11):3259-65.

108. Mittal V, Sharma P, Sharma B, Sarin S. Treatment of minimal hepatic encephalopathy: A randomised controlled trial comparing lactulose, probiotics and l-ornithine l-aspartate with placebo. Hepatology. 2009;50(4 Suppl):41A.

109. Bajaj JS, Saeian K, Christensen KM, Hafeezullah M, Varma RR, Franco J, et al. Probiotic yogurt for the treatment of minima hepatic encephalopathy. Am J Gastroenterol. 2008;103(7):1707-15.

110. Rayes N, Seehofer D, Theruvath T, Schiller RA, Langrehr JM, Jonas $S$, et al. Supply of pre- and probiotics reduces bacterial infection rates after liver transplantation-a randomized, double-blind trial. Am JTransplant. 2005;5(1):125-30.

111. Eguchi S, Takatsuki M, Hidaka M, Soyama A, Ichikawa T, Kanematsu T. Perioperative synbiotic treatment to prevent infectious complications in patients after elective living donor liver transplantation: a prospective randomized study. Am J Surg. 2011;201(4):498-502.

112. Pawlowska J, Klewicka E, Czubkowski P, Motyl I, Jankowska I, Libudzisz Z, et al. Effect of Lactobacillus casei DN-114001 application on the activity of fecal enzymes in children after liver transplantation. Transplant Proc. 2007;39(10):3219-21. 